Society for Range Management

View Points

\title{
Partnering for Rangeland Health on Tribal Lands
}

\section{Fixing a windmill with the right tools}

\section{By James McCuen, Diana Doan-Crider, and Bob Alexander}

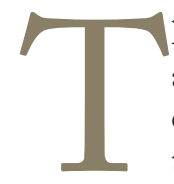

here is nothing more frustrating than trying to fix a windmill to get much-needed water to your cattle and wildlife, and then finding out that the tools that you normally use do not fit the parts on this particular model. Recently the SRM established the Native Range Initiative with the goal of helping America's First Nations restore and manage their rangelands back to health. But because this system has such complex management challenges, if this were a windmill, even the most experienced "well-man" would be scratching his head. Here we present our perspective about these complexities and the considerations we must make in order to facilitate Native Americans and their efforts to have sustainable rangelands.

The commitment for SRM to step up to the plate for this initiative and fulfill our mission to "promote continuing education of members and the public and the stewardship of rangeland resources" will call on us to truly combine the "art" and "science" of applied range management. The goal of this initiative is to promote creativity in developing new approaches that need to be "outside the box" of the conventional science and policy that we use to manage the range on nontribal lands.

The history of Native Americans in the United States lends itself to the challenge as much as the complexity of the lands themselves. Prior to the establishment of today's reservations and government regulation, there was a direct link between the land and Native American health, resulting in a very deep and intimate relationship with nature. But that relationship has changed significantly, and most Native Americans today have relatively little interaction with the land and its management. As Native Americans were forced to cede historic ranges to a rapidly growing and expanding western civilization, they were eventually either crowded onto the small unproductive remnants of their homelands, or completely removed and placed on unfamiliar reservations. For example, the Colville Reservation in north-central Washington today consists of 12 separate tribes that share an area that was twice as large in 1872 but was reduced to its present 2,100 square miles. Eventually the US government's intent to immobilize and separate the tribes from western society by reducing their natural contact with the land was effective. However, these actions became a set of stumbling blocks hindering the ability of tribes to manage their own resources and prosper autonomously within their own unique cultural traditions.

\section{A Brief History of Tribal Land Tenure and Policy}

The US government holds almost 55 million acres of land in trust for Native Americans, much of which is considered to be rangeland. ${ }^{1}$ These rangelands should be able to provide the foundational sustenance for Native Americans, habitat for native wildlife and livestock, and other resources needed for a high-quality life for tribal members. The Bureau of Indian Affairs (BIA) was established in 1826 to manage Indian affairs as one large agency from "the top down," including the management of their lands. Through the Allotment Act of 1887, lands were designated and managed as a "trust" by the BIA and were divided among individual tribal members in acreages between 40 and 160 acres for the purpose of farming. ${ }^{2}$ Over time, more complications entered into the equation as the more productive tribal lands were sold off as "surplus lands" to nontribal homesteaders or businesses claiming the need to produce food for a growing country, especially during wartime. This resulted in the highly checker-boarded land tenure pattern on some reservations today. Furthermore, the Allotment Act predestined the already small tribal allotments to become fractionated as they were passed down and divided among heirs over time. ${ }^{1}$ The Indian Land Tenure Foundation provides an example of one 160-acre allotment that ended up with 243 heirs over six generations, who all must agree on any land management decisions such as grazing leases to tribal or nontribal members. ${ }^{1}$ If allotments are leased out for grazing, lessees must locate and acquire permission from all owners and conform to BIA and tribal grazing policy. Today tribal 
allotments with hundreds of owners are common on some reservations, and often owners don't even know where their parcels are located. However, each tribe has a different history with varying degrees of trust vs. private lands.

During the 1970s, many of the US land management agencies fell under public scrutiny and were forced to make changes that were better for overall rangeland health vs. simply focusing on livestock numbers and production. Through the evolution of new concepts and science, they now manage rangelands through ecological site descriptions, rangeland improvements, and adaptive concepts such as rest rotation and adjusting livestock numbers accordingly. Because the BIA manages lands "outside" of the US public's reach, however, the agency remained somewhat isolated from this trend. As a result, many BIA personnel did not actively participate in organizations such as the SRM, and thus the agency has not necessarily been exposed to the newest and most relevant approaches.

At one point in time, it appeared that livestock production was one of the most promising avenues for tribal economic sustainability on rangelands, and many Native American cultures readily adapted to the lifestyle because of its similarity to bison hunting. ${ }^{3}$ But as agency directives shifted back toward farming and away from livestock production, livestock programs were disbanded and cattle were sold off from the trust lands. Those experiences still remain vivid in the minds of many tribal members who may have since acquired more cattle or leased out their allotments, and who have become accustomed to the predictable income from grazing leases. Convincing tribal councils and members that cattle numbers may need to be reduced or that new approaches need to be adapted to restore rangeland health has been a challenge for range managers who do want to incorporate these changes. However, the BIA will ultimately not go against tribal preferences because of their responsibility to administer trust lands for the tribes, even if it is evident that rangeland health might be compromised in some areas.

Other federal programs are available to tribal members through other US land management agencies such as the Natural Resource Conservation Service and Farm Service Agency for land and cattle herd improvements and loans, but those agencies also come with their own set of management plan requirements. In addition to BIA and tribal requirements, lessees are confronted with yet another set of management plan requirements, which may or may not be compatible with the others. Furthermore, many tribal members have a difficult time qualifying for government loan programs because of their lower-income brackets. This can become quite discouraging. If tribal members are willing to take on the challenge of grazing on trust lands, they must maneuver through a maze of bureaucracy to cross-fence or make improvements, and many times end up paying high lease fees. As a result, most tribal grazing plans become stifled, cattle are often unmanaged, and rangeland quality suffers as a result. In some cases, cattle and grazing become the culprits for many of the tribal natural resource woes, and range management receives less and less emphasis as a potential economic benefit for the tribe as a whole. In reality, many grazing leases are given to nontribal members who can afford legal counsel to maneuver through some of these complexities, who have larger herds and profits, or who can afford to make land improvements on their own or through government loans. Less than half of the income from agriculture on tribal lands is actually received by tribal members. ${ }^{1}$

\section{Economy}

Poverty and disease have invaded reservations simultaneously with resource degradation. Most early farming efforts failed because of cultural resistance, poor soils and/or arid lands, or lack of training. While livestock has been seen as a quasi-replacement for bison, it has been a struggle to promote livestock production as a form of capitalistic gain on many tribal rangelands for a number of reasons. For example, land tenure history often dictates a tribe's ability to accommodate and manage large herds. Some reservations are checker-boarded with allotted lands, where land becomes less productive and more fractionated through time. As tribal members leave to look for work or seek higher education, more and more absentee allotment owners become the main stakeholders and are unfamiliar and sometimes unconcerned about rangeland health simply because they never see the land. Land condition is also a limiting factor in that areas in the Southwest are less productive than those in the North. Cultural differences can play a role where cattle are frequently used as a shared food source for family members or neighbors, as a symbol of wealth, or as gifts during family events, but are not necessarily managed for profits. In these cases, herds may be small, and producers are forced to sell low-to-medium-quality sale-barn cattle, resulting in minimal profits (Delane Atcitty, Navajo Tribal Member and Beef Producer, personal communication). For some areas in the North, however, tribal members have been successful in leasing larger contiguous sections of land and produce high-quality cattle in larger herds (Zach Ducheneaux, Intertribal Ag Council, personal communication). While it is evident that there is no "one size fits all" approach to livestock management, successful models do need to be evaluated and adapted where possible to provide added economic incentive for managing rangelands and help tribes to become self-sufficient on their own lands.

\section{Education}

Older Native Americans already struggle with how they should feel about what's left of their lands and culture. The resulting bureaucratic quagmire has now made living off the land more of a battle than a lifestyle, the resource becomes 
degraded, and we are left with an injured relationship between a landscape and its people. So how do we convey something different to our young people and try to reconnect them back to the land? As children spend less and less time outdoors, and participation in groups such as $4-\mathrm{H}$ diminish, living off the land becomes less and less emphasized. Yet today's tribal youth carry the only hope that someday the tribes will be able to reestablish their cultural connection to the land, gain some independence from the US government, and become somewhat self-sufficient.

Education has always been a challenge for Native Americans both on and off the reservation because of funding, logistical problems and access to learning centers, and social difficulty in assimilating into western culture. These complexities likely contribute to reservation high school drop-out rates that can be as high as $60 \% .{ }^{4}$ However, in some areas, education is improving as tribes are learning how to combine western academic approaches without necessarily compromising traditional and cultural learning. Both are necessary to allow Native American students to survive in a rapidly changing and technological world and yet maintain their identity through their heritage. In addition, access to the Internet and capacity building for teachers and faculty have provided access to updated curricula. The establishment of the 1994 Land Grant College Program (tribal colleges) provides college access for many tribal students, and while most offer two-year degrees and certificate programs, several are now offering four-year and MS degree programs. More emphasis is needed in the area of natural resources because many of those degrees do not qualify candidates for upper-level supervisory or leadership positions, but programs such as the American Indian Higher Education Consortium and the US Department of Agriculture's 1994 Programs Office are now directing more attention and funding in those areas. Currently, most students seeking four-year degrees must leave their reservations and attend traditional western universities or colleges. However, one frequent complaint is that when students do leave the reservation for their education, they do not receive the cultural and traditional education that will help them cope with their own tribal issues and policies if and when they do return. Recently there has been an increasing interest in expanding tribal natural resource programs and training students to manage resources for their own tribes.

\section{Employment in Natural Resources}

Most positions in natural resources are located within the BIA, which is currently the largest land management agency for the tribes. Positions are limited to availability, however, so many times tribal members are not placed on their own tribal lands. While some tribes have recently begun taking on the challenge of managing their own resources, positions are fairly limited and insufficiently funded. Tribes are able to enter into a "Self-Determination" 638 Contract to manage tribal resources under tribal and BIA policies using federal monies. Due to the history, size, and control of the BIA over tribal affairs, it is difficult to foresee a complete separation between the tribes and the BIA when it comes to the management of natural resources. However, some tribes have been fairly successful in developing healthy working partnerships between themselves and BIA personnel, which seems to be a model worth exploring. Tribal management of natural resources is becoming more relevant, given that if cultural and traditional ties can be strengthened in the community, it can provide a sense of purpose, empowerment, and stewardship for the youth. In this case organizations such as the SRM should to be ready to assist with education programs that tie in to employment opportunities in natural resources, complement tribal cultural and traditional teachings, and help prepare their youth for the task ahead.

\section{Fixing the Windmill}

So, how do we go about getting water from a windmill that's been patched too many times using tools that don't fit? We, and many of our colleagues, now feel that tribal rangelands are in serious condition, and that drastic measures must be taken in order to restore them back to health. The role of the SRM in the new Native Range Initiative is to serve as a facilitator in bringing the necessary stakeholders together and providing them with a forum to develop new approaches that use the appropriate tools for Native American culture, social issues, and land tenure patterns. Hopefully the expertise provided by our members can support tribal initiatives with important scientific methods and training in range management. We would also like to see the SRM partner with the tribes in student training, while allowing for the inclusion of their own traditional and cultural values. This will require a significant effort from the SRM to learn, understand, and embrace a new way of thinking for this partnership and remain committed to helping the tribes overcome this challenge despite the likelihood of frustration and challenges. During the upcoming 65th Annual SRM Meetings in Spokane, Washington, in 2012, two full days will be dedicated to the management of rangelands on tribal lands and the Native Range Initiative, where we will also continue in our brainstorming session for the windmill model. Interested SRM members can contact any of the authors for details.

\section{Acknowledgments}

We would like to acknowledge Delane Atcitty, Zach Ducheneaux, and Jim Thorpe for their review of this article and for SRM's support of the Native Range Initiative. In addition, we would like to thank the conference organizers for the SRM's 65th Annual Meeting for prioritizing Native American issues.

\section{References}

1. Indian Land Tenure Foundation. 2010. Available at: http:// www.iltf.org/land-issues/trust-relationship. Accessed 14 July 2011. 
2. Wilkins, D. E., and K. Tsianina Lomawaima. 2001. Uneven ground: American Indian sovereignty and federal law. Norman, OK, USA: University of Oklahoma Press. 326 p.

3. Iverson, P. 1994. When Indians became cowboys: Native peoples and cattle ranching in the American West. Norman, OK, USA: University of Oklahoma Press. 266 p.

4. Engle, S. 2010. Report examines graduation rates among American Indian and Alaska native students in twelve states. Available at: http://civilrightsproject.ucla.edu. Accessed 14 July 2011.
Authors are Soils Technician, Confederated Tribes of Colville, PO Box 150, Nespelem, WA 99155, USA (McCuen); Lecturer and Faculty Member at the Department of Ecosystem Science and Management, Horticulture/Forest Science Building, Room 305, 2138 TAMU, College Station, TX 77843-2138, USA, d-crider@tamu.edu (Doan-Crider); and Range Specialist, Pueblo of Laguna, PO Box 194, Old Laguna, NM 87026, USA (Alexander). 